\title{
Strategies on mathematical thinking. A superior experience
}

\section{Estrategias sobre el pensamiento matemático. Una experiencia en superior.}

\author{
SOLIS-CAMPOS, Alicia †* \\ Centro de Investigación e Innovación para el Desarrollo Educativo \\ $1^{\text {st }}$ Author: Alicia, Solis-Campos / ORCID: 0000-0002-6573-4633, Researcher ID Thomson: F-6544-2019, arXiv Author \\ ID: AliciaSolis, CVU CONACYT ID: 374179
}

DOI: $10.35429 / \mathrm{JEH} .2019 .4 .3 .11 .17$

Received February 21, 2019; Accepted June 19, 2019

\begin{abstract}
The present article is a systematization of experiences derived from a workshop developed with higher education graduates working as teachers in basic or upper secondary education. The aim of the workshop was to strengthen the participants' competences in the design of didactic strategies focused on the development of mathematical thinking for their own students. The workshop addressed three specific teaching components: planning skills, learning environments and teaching strategies. It is important to highlight that an expected workshop outcome was a book chapter written with experiences drawn from the implementation of the designed didactic strategies. The ambition was to publish a book with financial support of the Research an Innovation Center and the Faculty of Exact Sciences. None of these two last objectives were fulfilled. The paper is divided in four parts: diagnostic evaluation, workshop design and implementation, participants's satisfaction and conclusions.
\end{abstract}

Learning environments, Education, Teaching strategies, Course evaluation, Planing

\begin{abstract}
Resumen
El presente artículo es una sistematización de experiencias derivadas de un taller desarrollado con graduados de educación superior que trabajan como profesores en educación básica o secundaria superior. El objetivo del taller fue fortalecer las competencias de los participantes en el diseño de estrategias didácticas enfocadas en el desarrollo del pensamiento matemático para sus propios estudiantes. El taller abordó tres componentes específicos de la enseñanza: habilidades de planificación, entornos de aprendizaje y estrategias de enseñanza. Es importante destacar que un resultado esperado del taller fue un capítulo de libro escrito con experiencias extraídas de la implementación de las estrategias didácticas diseñadas. La ambición era publicar un libro con el apoyo financiero del Centro de Investigación y Innovación y la Facultad de Ciencias Exactas. Ninguno de estos dos últimos objetivos se cumplió. El documento se divide en cuatro partes: evaluación diagnóstica, diseño e implementación del taller, satisfacción y conclusiones de los participantes.
\end{abstract}

Entornos de aprendizaje, Educación, Estrategias de enseñanza, Evaluación de cursos, Planificación

Citation: SOLIS-CAMPOS, Alicia. Strategies on mathematical thinking. A superior experience. Journal-Economic History. 2019. 3-4: 11-17.

\footnotetext{
* Correspondence to Author (email: magarcia@itess.edu.mx)

$\dagger$ Researcher contributing as first author
} 


\section{Introduction}

In basic education the subject of mathematics has been evaluated through national evaluations such as the National Plan for the Evaluation of Learning (PLANEA), which investigates among other things "the domain of mathematical learning of the corresponding educational level" (INEE, 2018 , p. 16), these evaluations are presented in four levels to be considered ranging from Level I or Insufficient to Level IV or Outstanding, resulting in $79.4 \%$ of students in levels I and II in elementary school. Also, in high school $89.4 \%$ and high school is not the exception (INEE, 2015), although these results are multifactorial, one of these causes is teaching and learning (Espinoza García, sf as cited in Corzo y Reyes, sf ; Luna, 2003), which is why the Center for Research and Innovation for Educational Development (CIIDE) suggests that basic education teachers have a tool that allows them to improve their educational practice, especially in the teaching of mathematics, through a book where they have proven strategies that help in the mastery of those mathematical learning of each educational level.

Given the possibility that the students of the Master in Educational Mathematics, of the Faculty of Exact Sciences (FCE) consider the objective of the workshop, that as part of their academic training, students strengthen their competencies for the design of teaching strategies that promote the development of the mathematical thinking of their own students and, with the existing agreement between said school and CIIDE, that the students, assisted with their tutors and thesis directors, apply and validate strategies in basic and upper secondary education, so that they are published in an edition of CIIDE / SEED together with the FCE / UJED, after the workshop designed for master's students. In this systematization of experiences, a little will be told about what happened during the intervention process, first what will be described in the diagnostic evaluation that was carried out in the first days of the course will be described, and it was through a process of open questions, where the masters students are characterized. The structure and development of the workshop will also be developed, in this section the way in which the students were working and about the products made will be announced, to finalize with the evaluation made by the students to the workshop called satisfaction of those involved.
Diagnostic evaluation.

Diagnostic evaluation.

Workshop structure and development

Due to the diversity of students in their academic training and teaching experience, adjustments were made so that students could consolidate what a strategy is, for that reason three important topics were reviewed: planning, learning environments and didactic strategies.

With regard to planning, some formats that students with teaching experience were reviewed, in addition to the characteristics that must be carried out, for this reason, the students established, after reviewing different formats and what Madrigal establishes and SolísCampos (2015) that the minimum that should have a didactic planning should be:

- Planning identification, where the name of the institution, name of the teacher, name of the subject to be taught, grade, group, shift, subject and date of preparation.

- Characteristics of the group, where they established a little of their diagnostic evaluation, how many students, internal and external context, among other relevant information.

- Information on the subject or subject: subject to be taught, objective, purpose, expected learning, skills to develop, etc.

- Development of activities, where activities of beginning, development and end could be visualized, dates on which they will be carried out, material to be used.

- Evaluation, the types of evaluation that you will use in your group, diagnostic, formative and summative, in addition to the coevaluations, self-evaluations and those made by the student to the teacher. 
In the second topic related to learning environments, three definitions were discussed in class: the one established by Raichvarg (1994, as Duarte cites, 2003) where he mentions that the environment derives from the interaction of man with the natural environment that surrounds; Ospina (1999, as Duarte cites it, 2003) that conceives the environment as a daily construction, of daily reflection, permanent singularity, which must ensure the diversity and richness of life in relation; and finally that it is considered as "a scenario where favorable learning conditions exist and develop. A space and a time in movement, where participants develop capacities, competencies, skills and values "(A.C. CEP Parras 1997, pp. 15-18 as quoted by Duarte, 2003).

This last definition was the one that was considered in the group to carry out the activity where they considered the technological and non-technological resources that were at hand in basic education, such as video production, collaboration websites, mobile broadband, applications hybrid web, collective intelligence, social operating systems, books, notebooks, and other materials that help in the generation of school environments conducive to learning (Correa, 2008 and Duarte, 2003), which they used to prepare a writing and answer the question What should I do to create the learning environment for my students?

The students had to consider the organization of the space, the materials, as well as rules and attitudes in the development of the activities, but give special importance to the sociomathematical norms, typical of the mathematical community and which are listed below (Bonacina, 2013):

- Methodological order: learn to solve problems.

- Cognitive order: learn concepts and procedures.

- Attitudinal order: that create the environment for the renegotiation of mental models that hinder when they do not preclude the development of the skills required for meaningful comprehensive learning.
For this activity there were those who did it as a painting and who in free text, but all the students made their proposal in the arrangement of the material (books, notebooks, cards, tables, blackboards, etc.), in the organization of the students and in organizing your own planning to design your classes. Finally, in the last part of the workshop we worked with the master's students in the identification of what is didactic, teaching method, sequence and didactic strategy, based on strategies established with Cortizas and Rodríguez de Castro (2007), Madrigal, Solis Campos y Reyes (2016), Ministry of Public Education, (2004) and other authors that each student investigated

Rosales (1988) establishes didactics as a science belonging to the systematic teaching process in terms of the organization of learning, while Contreras (1991) determines that it is a discipline that explains the teaching and learning processes to propose its realization consistent with educational purposes Given these two definitions students found similarities and built their own. Monereo (1994) definition of teaching method was taken into account, considering it as an orderly sequence of activities and resources used by teachers in their educational practice, since it is a logical achievement of the steps or activities that are carried out conducted for the purpose of an educational purpose, giving examples such as methods: deductive, inductive, or Montessori. Regarding the didactic sequence, it was considered as a series of activities to address a topic, which should be progressive and according to the knowledge and skills that the student develops (Cortizas and Rodríguez de Castro, 2007)

For the last concept reviewed within the didactic strategies, the definitions that Cortizas and Rodríguez de Castro (2007) were reviewed, because they first define it as the art of directing, weighing, controlling actions for the achievement of learning and then making an extension of this definition considering it as conscious and intentional actions for the accomplishment of a task, which must be based on a method, and implies a planning of the teaching and learning process in which the teacher must make decisions about the techniques and activities that he will perform in his classroom 
After analyzing the different definitions, the students present two instruments of Herrman's brain quadrant model (one as students and the other as teachers) which represent "four different ways of operating, thinking, creating, learning and, in short, live with the world "(Ministry of Public Education, 2004, p.7) obtaining the results presented in Table 1.

\begin{tabular}{|l|r|r|}
\hline \multicolumn{1}{|c|}{ Brain quadrants } & As students & As teachers \\
\hline Left cortex & $100 \%$ & \\
\hline Right cortex & $11 \%$ & \\
\hline Limbic right & & $88 \%$ \\
\hline Left limbic & & $44 \%$ \\
\hline
\end{tabular}

Table 1 Results in percentage of the evaluation to the students of masters of mathematics educativa Source: own creation

As can be seen in Table 1, each student could present more than one brain quadrant in their way of learning, so it was observed that when they behave as students, their processes are of analysis, reasoning and logic, they like models, theories , the precise word, collect facts, so that their competencies go to abstraction, mathematical, quantitative, problem solving.

On the other hand, as teachers they are in the limbic area, which sounds logical, since those in the left limb have as competencies the administration, organization, implementation carried out, necessary to implement the classes, and also those of the right limbic.

They are given teaching, teamwork, relational skills, much needed skills for educational practice.

Assessing their way of learning was important, because that way, strategies designed according to their results could be generated, such as, the strategy of illustrations or visual thinking, that of interleaved questions, that of topographic clues, that of abstracts, of previous organizers, analogies or metaphors (Education for Development Foundation, 2009).

As a couple, students, except one person who worked individually, worked on mathrelated strategies that were applied in the classroom, and delivered their sustained strategy.

\section{Satisfaction of those involved}

At the level of satisfaction of those involved, an instrument is applied that contains both closed and open questions, in both questions are asked regarding the organization of the program, the content of the course, the duration and the schedule, regarding who imparts the course, didactic means that were used, facilities and technical means, learning evaluation mechanisms, the general assessment of the course and the degree of satisfaction, with general comments. In the quantitative evaluation, they were asked to rate each aspect with a scale that ranged from 1 to 4 , where one strongly disagrees and four, completely agree, when analyzing the aspects, the results presented in the Table 2.

\begin{tabular}{|c|c|c|c|c|}
\hline \multirow[t]{2}{*}{ No. } & \multirow[t]{2}{*}{ Appearance } & \multicolumn{3}{|c|}{ Punctuation } \\
\hline & & Mean & Median & Mode \\
\hline 1 & $\begin{array}{l}\text { The course was } \\
\text { well organized } \\
\text { (information, } \\
\text { compliance with } \\
\text { dates and times, } \\
\text { delivery of } \\
\text { materials). }\end{array}$ & 3.22 & 3 & 3 \\
\hline 2 & $\begin{array}{l}\text { The number of } \\
\text { students in the } \\
\text { group was } \\
\text { adequate for the } \\
\text { development of } \\
\text { the course. }\end{array}$ & 3.78 & 4 & 4 \\
\hline 3 & $\begin{array}{l}\text { The contents of } \\
\text { the course } \\
\text { responded to my } \\
\text { training needs. }\end{array}$ & 3.33 & 3 & 3 \\
\hline 4 & $\begin{array}{l}\text { There was an } \\
\text { adequate } \\
\text { combination of } \\
\text { theory and } \\
\text { practice } \\
\text { application. }\end{array}$ & 3.22 & 3 & 3 \\
\hline 5 & $\begin{array}{l}\text { I can put into } \\
\text { practice the } \\
\text { contents } \\
\text { addressed in the } \\
\text { course. }\end{array}$ & 3.67 & 4 & 4 \\
\hline 6 & $\begin{array}{l}\text { The duration of } \\
\text { the course was } \\
\text { sufficient } \\
\text { according to its } \\
\text { objectives and } \\
\text { contents. }\end{array}$ & 2.67 & 3 & 3 \\
\hline 7 & $\begin{array}{l}\text { The schedule } \\
\text { favored the } \\
\text { attendance to the } \\
\text { course. }\end{array}$ & 3.22 & 3 & 3 \\
\hline 8 & $\begin{array}{l}\text { The way of } \\
\text { teaching or } \\
\text { tutoring the } \\
\text { course facilitated } \\
\text { learning. }\end{array}$ & 3.22 & 3 & 3 \\
\hline
\end{tabular}

SOLIS-CAMPOS, Alicia. Strategies on mathematical thinking. A superior experience. Journal-Economic History. 2019 


\begin{tabular}{|c|c|c|c|c|}
\hline 9 & $\begin{array}{l}\text { They showed } \\
\text { mastery of the } \\
\text { subjects taught. }\end{array}$ & 3.33 & 3 & 3 \\
\hline 10 & $\begin{array}{l}\text { The } \\
\text { documentation } \\
\text { and materials } \\
\text { delivered were } \\
\text { understandable } \\
\text { and adequate. }\end{array}$ & 3.56 & 4 & 4 \\
\hline 11 & $\begin{array}{l}\text { The teaching aids } \\
\text { were topical. }\end{array}$ & 3.22 & 3 & 4 \\
\hline 12 & $\begin{array}{l}\text { The facilities } \\
\text { were appropriate } \\
\text { for the } \\
\text { development of } \\
\text { the course. }\end{array}$ & 4 & 4 & 4 \\
\hline 13 & $\begin{array}{lr}\text { The technical } \\
\text { means } \\
\text { adequate tere } \\
\text { develop the } \\
\text { course content. }\end{array}$ & 3.78 & 4 & 4 \\
\hline 14 & $\begin{array}{l}\text { Instruments or } \\
\text { techniques of } \\
\text { evaluation and } \\
\text { self-evaluation } \\
\text { were available } \\
\text { that allowed to } \\
\text { know the level of } \\
\text { learning } \\
\text { achieved. }\end{array}$ & 3.22 & 3 & 3 \\
\hline 15 & $\begin{array}{ll}\text { The course } \\
\text { allowed me to } \\
\text { obtain } & \text { an } \\
\text { accreditation } & \\
\text { where } & \text { my } \\
\text { performance } & \text { and } \\
\text { learning } & \text { was } \\
\text { recognized. } & \\
\end{array}$ & 3.11 & 3 & 3 \\
\hline 16 & $\begin{array}{l}\text { The course } \\
\text { contributed to my } \\
\text { professional } \\
\text { development }\end{array}$ & 3.56 & 4 & 4 \\
\hline 17 & $\begin{array}{l}\text { The course } \\
\text { allowed me to } \\
\text { acquire skills or } \\
\text { knowledge that I } \\
\text { will apply in my } \\
\text { role. }\end{array}$ & 3.67 & 4 & 4 \\
\hline 18 & $\begin{array}{lr}\text { The } & \text { course } \\
\text { favored my } \\
\text { personal } \\
\text { development. }\end{array}$ & 3.44 & 3 & 3 \\
\hline
\end{tabular}

Table 2 Quantitative course assessment Source: own creation

When considering the aspects mentioned in Table 1 and combining them with the comments of the open questions, the following is established as conclusions:
1. Organization of the program The quantitative aspects were established with questions 1 and 2 ; where it is observed that the course was well organized $(\bmod =3)$ in addition to the fact that the number of students was sufficient for the development of the course $(\bmod =3)$, however, in their qualitative comments they state that the time was insufficient, especially for some activities (A102, A105), that they liked that there were modifications in the activities according to their learning pace (A107) and that the development of the teaching strategy was useful to them and that is where they would have liked to have more time in the program (A105, A107, A109).

2. Course content. The quantitative aspects were established with questions 3, 4 and 5, which stated that the course contents responded to their training needs $(\operatorname{Mod}=3)$, there was an adequate combination of theory and practice application $(\operatorname{Mod}=3)$, In addition to putting into practice the contents addressed (Mod = 4), however, in the comments received in this regard they were "quite broad and solid" (A102, 20b) and "although it was not the objective to work more with class planning it would have been helpful "(A107, 20b).

3. Duration and schedule The quantitative aspects were established with questions 6 and 7 , which stated that both the duration of the course and the schedule favored the fulfillment of objectives, contents and their attendance $(\mathrm{mo}=3)$, however in their comments it was written that time was lacking to work with ease the issues, especially the activity related to the strategies (A101, Al02, Al03, A105, Al07, A109).

4. Trainers or tutors. The quantitative aspects were established with questions 8 and 9 which stated that the way of teaching the course facilitated learning $(\mathrm{mo}=3)$ and showed mastery of the subjects taught $(\mathrm{mo}=$ 3 ), and in this aspect there were no comments about.

5. Didactic means. The quantitative aspects were established with questions 10 and 11 , which stated that the materials delivered were understandable to them $(\mathrm{mo}=4)$ and that they were topical $(\mathrm{mo}=4)$, so the only comment made was " very well explained and implemented"(A102, 20e). 
6. Facilities and technical means. The quantitative aspects were established with questions 12 and 13, which stated that the facilities were appropriate $(\mathrm{mo}=4)$ and the technical means also $(\mathrm{mo}=4)$, however, their comments were about the use of the computer that was assigned to the teacher, can improve (A101, A109) and what was had was "well used" (Al02, 20f).

7. The mechanisms of learning evaluation. The quantitative aspects were established with questions 14 and 15 which stated that they had evaluation and self-assessment techniques that allowed them to know their level of learning achieved $(\mathrm{Mo}=3)$ and the course allowed them an accreditation where they recognized their performance and learning $(\mathrm{mo}=3)$, however, in the qualitative aspects, it was commented that there were some criteria to evaluate some products (A101, A109), although the comment "very good, depending on the subject studied" (A102) was also made.

8. General assessment of the course. The quantitative aspects were established with questions 16, 17 and 18 where they state that the course contributed to their professional development $(\mathrm{mo}=4)$ allowed them to acquire skills that they will apply in their function $(\mathrm{mo}=4)$ and favored their personal development (Mo = 3), however, qualitatively, only comments are presented regarding what they liked but that the question of time was corrected (Al02) and that regarding the topics discussed "they seemed important to strengthen knowledge and improve teaching practice" ( A108, 20i)

At the end with the question regarding degree of satisfaction, only 2 students representing $22 \%$ indicate they are very satisfied with the workshop course, and $78 \%$ rate the course as satisfied.

\section{Acknowledgments}

Thanks to the Faculty of Exact Sciences of the Juárez University of the State of Durango and the Center for Research and Innovation for Educational Development, without whom the workshop could not have been carried out with graduate students.

\section{Conclusions}

The students of the workshop, managed to learn a respect on how to do a planning, and those who already had the experience, improved their processes, initially, especially those who were not professors by profession, were fearful of the knowledge that for them represented something different, but throughout the workshop they were more critical of their own effort, they were able $(100 \%$ of the students) to synthesize information regarding learning environments and apply them in strategies that they designed and applied within the classroom. Although one of the objectives was not achieved, which was the publication of a book, (due to generalized decisions of the majority of the teachers involved) it was achieved that the student could apply in a strategy the knowledge obtained for planning, the generation of environments and content adequacy.

\section{References}

Bonacina, M. (2013) Las normas sociomatemáticas y la enseñanza de la matemática. Recuperado de: http://casanchi.com/did/normassm01.htm

Contreras D., J. (1994) Enseñanza, currículum y profesorado. España: Akal

Correa Z., F. J. (2008) Ambientes de aprendizaje en el siglo XXI. E-mail Educativo 1(1), pp. 1-8 Recuperado de: https://revistas.unal.edu.co/index.php/email/arti cle/view/12622

Cortizas, I. J. y Rodríguez de Castro, S. C. (2007) Diagnóstico e intervención didáctica del lenguaje escolar. Recuperado de: http://ruc.udc.es/bitstream/2183/11876/2/97884 97450621.pdf

Corzo S., C. y Reyes E., C. M. (s.f.). Principales causas de reprobación de alumnos de los grupos de quinto semestre grupo seis y ocho de la escuela preparatoria número tres. (capítulo 1. Antecedentes). Universidad Autónoma del Estado de Hidalgo. Recuperado de https://www.uaeh.edu.mx/scige/boletin/prepa3/ $\mathrm{n} 7 / \mathrm{p} 1 . \mathrm{html}$ 
Duarte D., J. (2003) Ambientes de aprendizaje. Una aproximación conceptual. Estudios Pedagógicos, 29, pp. 97-113 Recuperado de: http://dx.doi.org/10.4067/S0718-

07052003000100007

Fundación Educación para el Desarrollo, Fautapo (2009) Manual de estrategias didácticas. Bolivia: CROMA, Consultora en comunicación

INEE (2015) Banco de indicadores educativos.

Recuperado de http://www.inee.edu.mx/index.php/bases-dedatos/banco-de-indicadores-educativos

INEE (2018, mayo) Plan Nacional para la Evaluación de los Aprendizajes (PLANEA). Documentos rectores. México: Autor. Recuperado de http://publicaciones.inee.edu.mx/buscadorPub/P 1/E/305/P1E305.pdf

Luna Treviño, M. A. (2003) Estudio diagnóstico: factores dependientes del alumno que influyen en la reprobación en el área de matemáticas en el primer semestre de la carrera de Químico Farmacéutico Biólogo de la Facultad de Ciencias Químicas de la UANL.[Tesis de maestría]. México: Universidad Autónoma de Nuevo León. Recuperado de: http://eprints.uanl.mx/5381/1/1020149250.PDF

Madrigal O. G., y Solís-Campos, A. (2015). Competencias docentes para la planeación didáctica multigrado. 1. Planeación didáctica argumentada en la escuela multigrado. Taller autoadministrable. Durango, México: Secretaría de Educación del Estado de Durango, Centro de Investigación e Innovación para el Desarrollo Educativo. Innovación para el Fortalecimiento del Sistema Básico de Mejora Educativa en Durango.

Monereo C. [Coord] (1994). Estrategias de enseñanza y aprendizaje. Formación del profesorado y aplicación en la escuela. Barcelona, España: GRAO

Rosales, C. (1988) Didáctica, núcleos fundamentales. Madrid España: Narcea

Secretaría de Educación Pública (SEP) (2004) Manual de Estilos de aprendizaje. Material autoinstruccional para docentes y orientadores educativos. México: Autor 